\title{
MORTGAGE RENEWALS IN ALBERTA
}

\author{
E. MIRTH*
}

\begin{abstract}
The subject of mortgage renewals has become important in light of the shorter term mortgages being given today. The author reviews some of the more important decisions in this area and highlights some of the pitfalls that can occur when renewing a mortgage, concentrating mainly with the "peculiarities" of Alberta law.
\end{abstract}

\section{INTRODUCTION}

The subject of this paper is a relatively "new" one, perhaps largely because shorter-term mortgages are relatively new. Until the end of the 1960's it was probably more common for mortgages to bear a term of five years or more, and many mortgages bore terms of twenty-five to thirty-five years. In more recent times, however, terms of six months, one year, two years and three years have become much more common. Indeed, in the single-family-mortgage context the norm today is probably something less than five years.

Unfortunately, most mortgage lenders' approaches to "renewals" tend to be arranged with a stress on simplicity and unity of form across Canada, and in that respect are often insensitive both to the peculiarities of the law of this province and to the potential complexity of renewals generally.

Until quite recently, renewals were normally handled very casually. Most often the process of renewal occurred by a simple letter from the lender, sometimes signed and returned by the borrower and other times not. Today, lenders are becoming a little more sophisticated in their approach to the subject, and more formal renewal agreements are increasingly common (although letter renewals remain common on single-family loans).

\section{BACKGROUND POINTS}

A few background points that should be noted in considering how renewals should or might properly be handled in Alberta are the following:

\section{A. A MORTGAGE IS A CHARGE}

It should first be noted that under s. 106 of the Land Titles Act ${ }^{1}$ a mortgage in Alberta operates merely as a charge. There is no conveyance of the legal estate. The primary aspect of the Land Titles Act mortgage is thus the promise to pay; the securing of the land in a sense is collateral to that promise. This concept may be important when one addresses the issue of "novation" in respect of mortgage renewals.

\section{B. CARRY-OVER OF PERSONAL COVENANTS}

Next it should be noted that s. 62(1) of the same act provides for the carry-over of personal covenants contained in mortgages from transferee

\footnotetext{
* Barrister \& Solicitor with the firm of Reynolds, Mirth \& Côté in Edmonton.

1. R.S.A. 1980 , c. L-5.
} 
to transferee, creating, with each transfer registration, an implied covenant directly with the mortgagee and with the transferor in regards to payment of mortgage principal and interest:

\begin{abstract}
In every instrument transferring land for which a certificate of title has been granted, subject to mortgage or encumbrance, there shall be implied the following covenant by the transferee both with the transferor and the mortgagee: That the transferee will pay the principal money, interest, annuity or rent charge secured by the mortgage or encumbrance, after the rate and at the time specified in the instrument creating it, and will indemnify and keep harmless the transferor from and against the principal sum or other money secured by the instrument and from and against the liability in respect to any of the covenants therein contained or under this Act implied on the part of the transferor. [Emphasis added.]
\end{abstract}

Apart from s. 62(1) (and apart from direct contract), there would be no contractual nexus between a mortgagee and subsequent transferees of land. There might well be indemnities between transferors and transferees, either express or implied on the contract of sale between those parties. The mortgagee, on the other hand, would obtain a direct nexus with the transferee only by virtue of either an assignment by a transferor of his contractual right against the transferee or by virtue of having the transferee attorn directly to the mortgagee in some fashion. The latter could conceivably operate as a "novation" of the mortgage, if the principal mortgagor is released; but s. 62(1), which by the indemnity of the transferor contemplates liability of the transferor continuing, hopefully makes that kind of concern for novation inapplicable to a simple transfer.

As will be seen from the discussion of some recent cases hereinafter, there may well be distinct rules applicable in Alberta by virtue of a statute implying covenants directly with the mortgagee. On balance, the peculiar structure of Alberta's s. 62(1) should bear more on the issue of release of prior obligors than on the issue of novation; but there is some basis to be concerned about it bearing on novation as well.

In addition, it is noted that s. 62(1), as does the mortgage form prescribed under the Act, seems to contemplate only mortgages that (as per the words emphasised above) specify rates and times for payment, and also only implied covenants as to matters contained in the mortgage itself. That is to say, the statutory covenant by transferees with the mortgagee seems to apply only to matters specified in the mortgage. That may bear on the appropriateness of any renewal a lender wishes to have bind subsequent transferees. It may also bear on the question of "novation" insofar as it would almost seem to contemplate that a mortgage will remain unchanged.

\title{
C. PERSONAL COVENANTS NON-ACTIONABLE FOR INDIVIDUALS
}

Section 41(1) and ss. 43 to 43.4 of The Law of Property Act $^{2}$ make personal covenants non-actionable for individual mortgages and for individuals who become owner-occupants of farms and residential properties. Accordingly, the position of various mortgagees or property owners, insofar as personal recourse on covenants to pay is concerned, may vary

2. R.S.A. 1980, c. L-8. 
from time to time through the history of a mortgage. They may even be

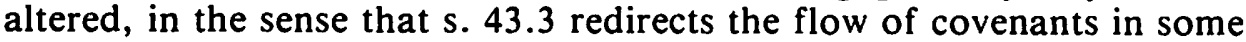
situations. ${ }^{3}$

\section{UNAUTHORIZED ALTERATIONS}

There is a general principle applicable in contracts law, in the context of unconsented changes to a contract by a party thereto, that may bear significantly both on the matter of "novation" and the enforceability of covenants against parties not consenting to the change. The principle is expressed in An Introduction To The Law of Contracts ${ }^{4}$ as follows:

The common law gave great sanctity to a written contact and imposed sanctions for falsification of the evidence which it afforded. Therefore, any written contract was held to become void if it was subjected to an unauthorized alteration in any material respect by someone other than the grantor of the obligation. This may seem a harsh penalty, but it was apparently designed to make the creditor keep the document intact and unaltered at his peril. . .

It is graphically expressed in the result in a case in which a creditor added legal seals (wafers) to an instrument without consent after execution and the court held the instrument void due to material alteration. ${ }^{5}$ It was also expressed in a mortgage situation in St. Mary's Savings \& Credit Union Ltd. v. Smith, ${ }^{6}$ where the Saskatchewan Court of Appeal declined to enforce a mortgage that appeared to have clauses added to the mortgagee's copy of the mortgage (and that were not in the mortgagor's copy), which the trial court had found were added by the mortgagee after execution.

If a renewal releases prior covenantors by operation of this principle, that of itself can be a matter of some concern; but does such a renewal, by joining current owner's direct covenants to pay with the legal result of release of prior covenants, not also bear many, if not all, of the hallmarks of a novation?

\section{PROBLEMS POSED}

For the most part, renewal of mortgages would be a relatively easy thing if there were never any changes in the parties involved in the mortgage. If the mortgagee and the mortgagor remained the same parties then, presumably, the matter of renewal could be handled by a simple contract to amend. Such contract could be a mere contract in personam to extend time for payment or it could be an amendment of the security instrument itself. If the renewal involved any increase in the rate of interest or other new exactions to which the mortgagee will be entitled, the renewal would plainly have to go further than mere in personam operation and create a charging of the additional costs against the land (i.e. have an in rem impact and operate as an amendment of the mortgage).

Further, if there are encumbrances subsequent to the mortgage and any additions to the entitlement of the mortgagee (for example, increase in interest rates), then it would be necessary, in order to bind the subse-

3. In that regard it differs significantly from s. 41 , which merely restricts remedies without touching the covenant itself.

4. J.E. Côté, An Introduction to the Law of Contracts, (1974) at 221.

5. Petro Canada Inc. v. Tormac Transport Ltd. [1983] 4 W.W.R. 205 (B.C.S.C.).

6. (1983) 29 Sask. R. 159. 
quent encumbrancees to the altered terms, to secure undertakings or postponements from the subsequent encumbrancees.

Lastly, even in the straight-forward same-party renewal, some concern for the position of the mortgagee on a locked-in mortgage would apply, as the cases hereinafter discussed would make clear. Short of these points, however, the process would be fairly uncomplicated on renewals with the original mortgagor.

Where the parties relevant to the property and the mortgage have changed, however, a whole mess of additional problems arise. A change in ownership raises the complex problem of "novation" above referred to. A change in ownership could involve a change in the character of the mortgage from "corporate" to "individual". A change in the kind of use made by a subsequent purchaser (for example the change in use from rental to owner-occupancy) could have the effect of a practical change in enforceability of the personal covenants by virtue of the 1983 Law of Property Act amendments. ${ }^{7}$ These circumstances in turn could add to the concern about the possibility of novation.

After title changes occur, a serious question arises apart from novation as to who is bound by the renewal arrangement. Are prior owners (mortgagors) bound by changes? What is their position or character after the promise to pay? Are they still primary promissors or do they become a sort of "surety"? Do subsequent owners, who take over the title subject to the registered mortgage, become bound by the changes that are made (if not registered, or even if registered by caveat)? Can the renewal truly be treated as a mortgage amendment for which s. 62 will operate even though the original mortgagor is not a party? Are subsequent interest holders bound if all the parties to the original mortgage and the current owners do not join in its modification?

Probably most serious in potential impact is the question of what is the legal nature of the renewal. If there has been any change in ownership and the renewal is made only between the current owner and the mortgagee and operates as more than a personal (or in personam) time extension, apart from whether that amounts to a novation and/or an accord and satisfaction of the earlier mortgage, does s. 41 of the Law of Property Act apply to the "new" mortgage if renewal is made with individuals? Or, more likely, does the renewal form a material alteration that releases or voids the contract of loan as against the prior mortgagor? Can it properly be treated as an amendment agreement for the original mortgage when the original mortgagor is not a party to it (and remains theoretically, at least, liable on the personal covenant that is the root of the mortgage)? Is the arrangement a merely personal extension agreement whereby the mortgagee agrees as a matter of personal arrangement with the then-current owner to extend the time for payment in return for altered terms of repayment? If it is merely a personal extension arrangement, what is its impact on subsequent purchasers? Can it operate, then, in rem at all? 
What is the effect of a renewal on the obligations of guarantors? This question may apply not merely to persons who have signed personal guarantees but also to persons who may play a role like that of a guarantor, the prior mortgagors.

To what extent is registration of the renewal arrangement required, and to what extent will it be effective in law? Clearly, if the land is to be bound with any additional charging some form of registration is required. Clearly, as well, if subsequent buyers and encumbrancers are to be bound, registration in some form is required. Will a renewal agreement that operates merely as a personal arrangement for extension of the time for payment generate any legitimate interest in land that will support a caveat? If the renewal agreement is not properly an amendment of the mortgage (because it joins only the current owner and not prior owners) what is the basis for registration of any caveat? If the sole basis is to record the charging of additional interest (where the interest for example increases) would the caveat be protecting a brand new charging agreement between the current owner and the mortgagee? Is that charging agreement complete in itself?

What is the impact of s. 10 of the Interest Act of Canada on renewals? What is the "term of the mortgage" after renewal? Finally, what form should a renewal agreement take and (depending on what form it does take) what is the legal impact of the renewal?8

8. It is not intended herein to discuss handling of collateral security (other than guarantees) to any extent. The treatment of those matters is already a subject matter sufficient to warrant a separate paper; but more to the point it is a subject matter that will likely change dramatically if a Personal Property Security Act is adopted in Alberta (which seems imminent).

Some questions might nonetheless usefully be posed on the treatment of collateral security under the existing statutes. Collateral security on property other than that which creates an interest in land (e.g., a chattel mortgage, assignments of rents (as viewed to this date by the courts in Alberta), letters of credit, etc.) presents special problems. Our chattel mortgage legislation, for example, appears not to contemplate at all any instrument such as an amending agreement. Arguably an amending agreement altering interest rates, terms, and payments on a chattel mortgage is itself a "bill of sale" within the definition of the Bills of Sale Act, R.S.A. 1980, c. B-5: To the extent it extends a charge on chattels for an increased interest rate it seems to fall within the definition of "mortgage" which includes (s.1(i)) "an agreement . . . by which a right in equity to a charge or security on any chattels is conferred". With the land mortgage itself, the matter is easily handled under the Land Titles Act, R.S.A. i980, c. L-5, by the filing of a caveat. Whatever the operation of the renewal agreement, on land a caveat properly cast (and preferably annexing and incorporating the renewal agreement) should cover the matter at least insofar as title charging and security is concerned. (Quere, however, whether the stipulations will operate under s. 62 of the Land Titles Act, supra.) If no similar mechanisms exist for personalty (as opposed to realty) securities, then one is faced with a "Catch 22" situation: There seems to be no way to be sure of effectively binding the renewal terms without characterizing the renewal instrument itself as a new instrument, and so characterizing it lends credence to the "novation" position where the "new security" comes from a mortgagor other than the original mortgagor. And the "renewal" collateral security would not bear the priority of the original security.

If the renewal agreement merely agrees that collateral security is preserved and continued, there is at least some danger that the collateral security will not secure a rate increase (where there is one). Until the Courts fully outline the legal operation of renewal agreements, however, this limitation seems a lesser evil than the risk of novation. 


\section{RECENT CASES AND THEIR IMPACT}

To get some insight into the possible answers to some of the above questions and the serious degree of concern that surrounds them, a review of some of the cases recently decided offers some help. Unfortunately the cases to date have been rather sketchy and (particularly in the recent decisions out of B.C.) somewhat contradictory. Answers to many of the foregoing issues remain unclear as a result. For them, this paper can do no more than raise the questions and thereby point to the dangers they place in the conveyancer's path (and the litigator's as well, I suppose), with some hope for their avoidance.

\section{A. PREPAYMENT RIGHTS}

Most of the cases dealing with renewals, until quite recently, have revolved around the narrow question of prepayment rights applicable in the renewal term. Indeed, the one case that appears imminently to be heard in the Supreme Court of Canada is of that type. The cases of particular interest on this question are:

1. Re Hodgson ${ }^{9}$

2. Deeth v. Standard Trust Co. ${ }^{10}$

3. Lynch v. Citadel Life "1

4. Potash v. The Royal Trust Co. ${ }^{12}$

5. Butcherv. The Royal Trust Co. ${ }^{13}$

6. Rivardv. Canada Permanent Trust Company ${ }^{14}$

7. Re McDonald and The Royal Trust Corp. of Canada ${ }^{15}$

8. Shaw v. The Royal Trust Co. ${ }^{16}$

9. Re Cloval Developments Ltd. ${ }^{17}$

10. Turnerv. Royal Trust Corp. of Canada ${ }^{18}$

In the Deeth case the mortgage was not an unusual five-year mortgage. The period from the interest adjustment date to the maturity date was exactly five years. However, the mortgage instrument was (not surprisingly) dated and signed before the interest adjustment date. The mortgage was renewed on the initial maturity. Shortly after renewal the mortgagor sought to prepay and the mortgagee asked for a nine-month interest bonus. The mortgagor claimed that the mortgage was a mortgage with a term exceeding five years and therefore that a three-month bonus was all that could be exacted.

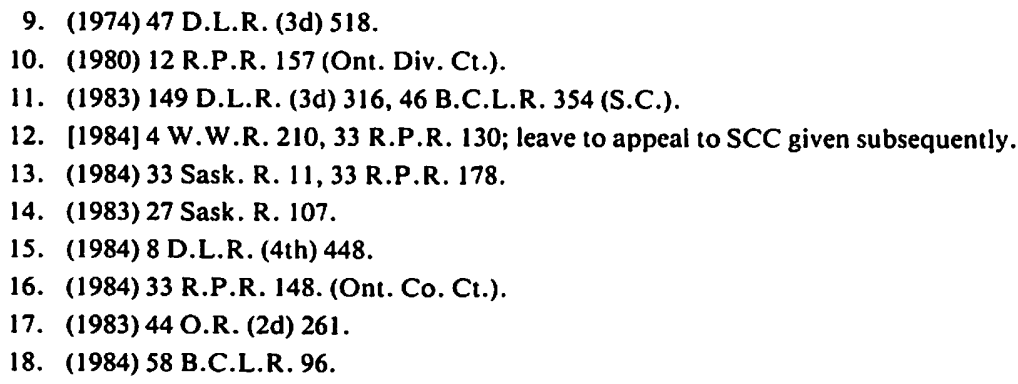

9. (1974) 47 D.L.R. (3d) 518.

10. (1980) 12 R.P.R. 157 (Ont. Div. Ct.).

11. (1983) 149 D.L.R. (3d) 316, 46 B.C.L.R. 354 (S.C.).

12. [1984] 4 W.W.R. 210, 33 R.P.R. 130; leave to appeal to SCC given subsequently.

13. (1984) 33 Sask. R. 11, 33 R.P.R. 178.

14. (1983) 27 Sask. R. 107.

15. (1984) 8 D.L.R. (4th) 448.

16. (1984) 33 R.P.R. 148. (Ont. Co. Ct.).

17. (1983) 44 O.R. (2d) 261.

18. (1984) 58 B.C.L.R. 96. 
The Court held that the five years under the relevant section of the Ontario Mortgages Act ${ }^{19}$ (which is similar to s. 10 of the Interest Act of Canada ${ }^{20}$ ran from the date of the mortgage. Therefore, the original mortgage under consideration was a five-year-plus mortgage.

The Court also held that whether the "renewal" was an extension agreement, an agreement for loan, or an amendment of the mortgage, one must still look to the original mortgage to see if the statute applies (in Alberta the statute relevant would, of course, be s. 10 of the Interest Act). If it does, then the bonus on the extended term is limited to three months.

In the earlier Ontario decision in Re Hodgson, the Ontario High Court had held that a renewal agreement for five years after a five-year initial term was in fact locked-in.

In the Lynch case, the B.C. Court tried to reconcile the Hodgson case with the Deeth case. The Court noted that in Hodgson the initial mortgage was dated as of the same date as the interest adjustment date. It therefore concluded that in Hodgson a five-year mortgage and not a fiveyear-plus mortgage was involved. (One might note that September 30th to September 30th may well be five years plus one day and querie in that context the validity of the distinction between the two cases). As the original mortgage in the Lynch case was five years plus some days, as in Deeth, the B.C. Court applied the Deeth decision.

Quite apart from the above two cases, one might question the effect of an extension of even a clearly-less-than-five-year mortgage. If the original mortgage is, in any view, a four-year mortgage, and is then extended another two years, does that make it a six-year mortgage? Or does the renewal stand on its own? The typical renewal agreement may well operate as an amendment of the original mortgage. If it does, then, after the amendment why would one not have, comprised in the original mortgage plus the renewal agreement, a six-year mortgage? If the renewal stands on its own, then does it amount to a separate and distinct mortgage? Or a novation?

On the other hand the Hodgson case has been criticised in a respected mortgage law authority: Falconbridge's 4th Edition:21

In Re Hodgson and Raskin a mortgage for a term of 5 years was extended for a further term of 5 years. The mortgage provided that the mortgagor was to retain the principal for the period of the extended term. During the renewal period the mortgagor sought to pay the outstanding principal pursuant to s. 10 of the Interest Act or s. 17 of the Mortgages Act. The court concluded that he could not do so. The word "terms" as used in both sections, was held to be referable to the conditions of the mortgage and not to two or more time periods created by the mortgage or its renewal. The inapplicability of the statutory provisions resulted from the fact that under the terms of the mortgage the principal was payable at a time nor more than five years from the date of the mortgage but became so payable only by virtue of the extension agreement, a situation not covered by the legislation. This conclusion is open to question. First, if the mortgage contains a renewal clause that clause is itself a term of the mortgage. Moreover the fiveyear period runs from the date of the mortgage and a renewal simply changes the date for redemption. If the renewal creates a new mortgage then the mortgagee's priority over encumbrances created after the original mortgage and before renewal would be

19. Now R.S.O. 1980 , c. 296 , S. $17(1)$.

20. R.S.C. 1970 , c. I-18.

21. Falconbridge, Law of Mortgages, (4th ed.) at $45-46$ (footnotes omitted). 


\begin{abstract}
lost. Second, if a mortgage is drawn for a term of five years, renewable at the option of the mortgagee, the policy of the legislation i.e., that certain mortgages are to be open after five years, could be negated. Finally, the ratio of the case would suggest that even if the renewal period had been in excess of five years the legislation would still not apply. Thus, if the renewal period had been ten years and the mortgagor wished to redeem after five years of that period, he would not have a right to do so. Such a conclusion seems in direct contradiction to the intention, if not the wording, of the sections.
\end{abstract}

The Potash case addressed the issue of whether a waiver of s. 10 of the Interest Act is effective. The trial court judge, Kroft $\mathrm{J}$. had held that a renewal agreement that in its express terms deemed the "date of the renewal to be the date of the mortgage" did not offend the public policy of s. 10 of the Interest Act of Canada and that such a stipulation resulted in there being no prepayment privilege during the term of the renewal.

In the Court of Appeal the trial court decision was reversed. The court ruled that because contracting out or waiver of s. 10 of the Interest Act is contrary to the policy of the statutory provisions, the renewals, notwithstanding their containing the "deemed date" clause and notwithstanding their containing a limitation on prepayment, contravened the Interest Act and could not stand. The court ruled that the fundamental point was that it was contrary to the policy of the Interest Act for a mortgagor to contract out or waive the provisions of that Act. It might be noted that this decision came out four days after the decision to the contrary of Brennen J. in the Alberta Court of Queen's Bench in McDonald v. Royal Trust Company.

Leave to appeal to the Supreme Court of Canada in the Potash case has been granted, although it is unlikely to be argued before fall of 1985 .

The Butcher case appears to have been decided after the Potash trial court decision and prior to the Court of Appeal decision. In Butcher, the original mortgage bore a five-year term (or, on the analysis of the Deeth case, a five-year-plus-one-month term). It was renewed in 1981 by a renewal that deemed the original mortgage to be dated as of its maturity date. It provided for only a ten per cent annual prepayment privilege.

The court held that the renewal term was locked-in (presumably subject to the ten per cent item). In so ruling, it referred to the Potash trial decision and other cases recently decided, from the Hodgson case to the Lynch case. Interestingly, the court concluded that notwithstanding the Potash decision at trial, s. 10 of the Interest Act could not be waived. In so doing, the Saskatchewan court almost anticipated the Manitoba Court of Appeal decision in Potash.

However, Wright $J$. went on to say (after referring to the nonwaivability of s. 10):22

There is an important corollary to that principal, however. If the borrower chooses to extend or renew his agreement with a lender for a further term, even though there is no change in the terms of the new arrangement save for the new dates for payment, then s. 10 only applies to the new term. It would be illogical and manifestly unjust if a mortgagor could renew an existing mortgage and then immediately retire his debt by simply paying the principal, interest and a sum equivalent to three months' interest.

In the Rivard case, the mortgage was originally placed in 1977 and renewed in 1980 for a term of five years. The property mortgaged was subsequently purchased by the plaintiffs in the case, who assumed the

22. Supran. 13 at 17. 
renewed mortgage. Neither the original mortgage nor the renewal contained any terms or provisions with respect to prepayment; and neither contained any terms as to any penalty that might be payable on prepayment. The plaintiffs sold the property and sought to obtain a payout statement. The lender gave them one calling for a three months' interest penalty. The plaintiffs claimed that the lender was not entitled to the penalty.

The Court held that the position of the plaintiffs was untenable. The plaintiffs had no prepayment right at all during the existence of the current term (five years not having passed), and would have to pay a threemonth bonus even after five years.

In the Shaw case, Scott Co. Ct. J. declined to apply the Deeth decision. The Court followed the decisions in B.C. (Kaltenbac v. Royal Trust Co.) ${ }^{23}$ and Manitoba (the decision in Potash of Kroft J.). In those cases it was concluded that a properly worded mortgage renewal agreement would prevent the mortgagors from arguing that they might prepay without restriction any time after the first five years of their mortgage elapsed. The clauses given effect to in those cases, limited rights of prepayment and deemed the "term of the mortgage" to be the term of the renewal agreement. The mortgage in the Shaw case contained similar provisions.

In applying the Kaltenbac and Potash cases, Scott Co. Ct. J. noted that he had some doubt whether he would come to the same conclusion if he had before him persons completely unfamiliar with legal technology. In the particular case before him the borrower was a life insurance salesman who had considerable experience in explaining the intricacies of life insurance policies and annuities and giving assistance and advice on overall financial planning. It could be assumed that he was reasonably familiar with the express terms of the renewal agreement that he signed.

The same "sophisticated" borrower approach was a factor in the decision of Kroft J. in the Potash case in Manitoba, however, as noted above, the trial court decision in Potash has since been reversed by the Manitoba Court of Appeal, although the matter still remains to be argued in the Supreme Court.

In the Cloval case, the original mortgage permitted prepayment at any time without notice or bonus. It also stated that the borrower, when not in default, would have the right to renew the mortgage for a further term of five years. At the end of the initial five year term, an agreement extending the mortgage was entered into and there was in the agreement no reference to the covenant for renewal or to the privilege of prepayment contained in the original mortgage. The extension was for only two years, not five years, and only interest was payable (as opposed to principal and interest). The Ontario Court of Appeal held that since the privilege of prepayment was not expressly provided for in the extension agreement, it was lost and the mortgage was irredeemable except on payment in conformity with the new agreed terms. 
In the Turner case the B.C. Supreme Court dealt with the essential nature of an extension agreement and held it not to be a new mortgage relationship, but an extension of, and part of, the original mortgage. In essence, it took the original mortgage and simply extended the term. In this case, unlike the other Royal Trust cases above mentioned, the renewals did not contain any specific "re-dating" provisions or waivers of prepayment rights. So viewed, the Court held that the extensions took what was originally a two-year term, and made it a longer term. As a result, once five years after the mortgage date had passed, the mortgagor could prepay.

From these cases on prepayment rights the following appears for the moment to sum up the situation:

1. For purposes of s. 10 of the Interest Act, the five-year period runs from the date of execution of the mortgage, not the interest adjustment date: Deeth and Lynch cases.

2. Where the mortgage original term and renewal are each clearly less than 5 years, there are reasonable chances that the renewal will be treated as a separate item for purposes of s. 10 of the Interest Act and can be locked-in: Hodgson and Cloval cases, provided that it is not expressed as a waiver of the Interest Act and provided the renewal clearly so intends.

3. Waiver of s. 10 of the Interest Act may not be the correct way to secure the lock-in, although until the matter is decided by the Supreme Court it remains moot: Potash case.

\section{B. NATURE OF THE RENEWAL: - IS IT A NOVATION? IS THERE A RELEASE OF PRIOR COVENANTS?}

If the renewal is something more than merely an extension, a whole collection of additional problems pop up: - not the least of which, as previously mentioned, are the concerns over novation, release of prior covenants, and possibly even accord and satisfaction. ${ }^{24}$ The desire to preserve the integrity of the original mortgage and also to avoid s. 10 of the Interest Act are at cross purposes. As the risks with half-done novations are far greater than mere loss of lock-in, the lender for whom lockin is especially important had best, perhaps, consider a whole new mortgage. A related and interlocking issue is the question of whether, even apart from novation, the position of prior covenantors is altered by renewal to yield some form of release.

A number of decisions in B.C., Alberta and Nova Scotia in the past two years have generated serious uncertainty as to the nature of a renewal in this province.

It should be remembered as a side note first that the nature of the renewal may be quite different in different situations. If an original mortgagor enters into a simple renewal of his mortgage, "novation" clearly is

24. This possibility must surely be remote. It would be most unusual to find in the intent, conduct or other inter-relations of the parties a credible suggestion that the original mortgage was satisfied and replaced. Even where the original mortgagor is defunct or his debt otherwise discharged (as on a winding-up, bankruptcy, etc.), surely no one would intend (or conclude as a matter of law) that the "old" mortgage was gone. The possibility cannot be totally rejected however. 
an unlikely issue on such renewal. On the other hand, if renewal occurs after several title changes, and is joined in by only the current owner, and materially alters the mortgage terms, there is, at least under Alberta statute, a more arguable issue. The cases discussed below for the most part involve renewals with subsequent owners.

The B.C. decisions illustrate best the division that can exist on this issue. In a series of four cases at the Supreme court level, all decided within months of each other, the results split 2 and 2 (albeit for varying reasons).

In Canada Permanent Mortgage Corporation v. Halet Enterprises $L t d .{ }^{25}$ a commercial property was subject to a mortgage that was granted by Halet Enterprises Ltd. and guaranteed by two parties. The property was sold to a Mr. Dick who assumed the mortgage. When the mortgage matured subsequently, Mr. Dick renewed at a $43 / 4$ per cent higher rate of interest. Halet Enterprises and the guarantors were not joined in the renewal agreement. When Mr. Dick later defaulted, the lender sought personal judgment against all parties. The B.C. Supreme Court held that the renewal with $\mathrm{Mr}$. Dick was a novation and that recourse against the original borrower could not be had. The claim against the guarantors failed for the same reason.

This case has been subsequently followed in an Ontario Supreme Court decision in Malaviya v. Lankin. ${ }^{26}$ In that case, a lender delayed in exercising remedies for a default and extended and altered payment arrangements past maturity, without any contact with, or reference back to, the original mortgagor. Holland $J$. found that in all the circumstances, there was a novation. In addition, following the earlier Ontario decision in Wald v. Pape ${ }^{27}$ and the Alberta Court of Appeal decision in Devenish v. Connacher ${ }^{28}$ the Court noted that by virtue of $s$. 19(2) of the Mortgages Act (which like Alberta's Land Titles Act s. 62 gives a direct covenant liability to the mortgagee), the original mortgagor became a surety and was discharged by the material alteration of the mortgage. In so doing, he applied the Holland-Canada Mortgage Co. v. Hutchin ${ }^{29}$ case mentioned below.

In Canada Permanent Trust Co. v. Carlyle, ${ }^{30}$ the defendants, Robert Carlyle and William Carlyle, bought a mortgaged property and assumed the mortgage. Subsequently, the mortgage was renewed on three occasions, although William Carlyle signed only the first renewal (Robert Carlyle signed all three). The rate went up on each renewal, to $131 / 2$ per cent, $18 \frac{3 / 4}{4}$ per cent, and finally $191 / 4$ per cent.

25. (1983) 30 R.P.R. 240.

26. (1984) 32 R.P.R. 252.

27. (1978) 22 O.R. (2d) 163. Leave to appeal was granted by Galligan J., to the Divisional Court ((1980) 28 O.R. (2d) 27), but Mr. Justice Holland held that the Divisional Court decision did not detract from the trial level decision on s. 19(2). Mr. Justice Holland rejected the High Court decision in Skoretz v. Ridgeport Developments LId. (1980) 28 O.R. 450, made without reference to Waldv. Pape, as incorrect.

28. [1930] 2 W.W.R. 254.

29. [1936] S.C.R. 165.

30. (1983) 30 R.P.R. 245 
Noting that the renewal agreements expressly stated that "all other terms and conditions of the mortgage not inconsistent with the terms of the renewal agreement will remain unchanged and in full force and effect", MacDonald J. held that the renewals were variations of the original mortgage, not novations.

However, drawing on a decision in the Supreme Court of Canada ${ }^{31}$ dealing with release of guarantees, MacDonald J. held that renewal at a higher rate of interest was not merely a matter collateral to the original contract and, as such, notwithstanding the wording of the mortgage, William Carlyle was no longer bound by the mortgage renewed at a higher rate. Even apart from that, the mortgagee having dealt with only one of the two owners could not bind the one who did not sign.

The Court also applied in favour of William Carlyle the cases that discuss non-enforceability of an altered contract (e.g. by deletion of a part, or an addition of something) as against a party who hasn't consented to the alteration. It was noted that the onus lies on the party seeking to enforce the mortgage to show that there was consent.

This decision might also have drawn support from a case in the Privy Council in $1982^{32}$ that held that the extension of a mortgage coupled with a material increase in interest rate (nine to sixteen per cent) released guarantors notwithstanding the express application of the guarantees to "future advances" and the express continuance thereof notwithstanding "any other indulgence or consideration".

In Eaton Bay Trust Co. v. Pollon, ${ }^{33}$ the property subject to a mortgage changed hands twice and was renewed by the second purchaser. On default, the lender sought personal judgment against the original borrower. On the renewal the interest rate dropped $31 / 2$ per cent. Catliff L.J.S.C., held that on transfer, the original borrower did not become a guarantor (as he might be, His Lordship suggested, in Alberta or Ontario). He remained a primary covenantor. In that regard, it would appear from the judgment that the B.C. equivalent of Alberta's Land Titles Act s. 62 provides only for an implied covenant of indemnity with the transferor, not a direct covenant with the mortgagee. The court held that, as there was no new primary debt relationship by the purchaser to the lender. The original borrower remained (as the only direct covenantor) the primary debtor, not a guarantor. The discussion in this decision of the equivalent to s. 62 of Alberta's Land Titles Act would suggest that the result would be quite different in Alberta. This has also been suggested in the Prince Edward Island case, Royal Trust Company v. Reid ${ }^{34}$ and in the Ontario decisions of Wald v. Pape ${ }^{35}$ and Malaviya v. Lankin. ${ }^{36}$

The Court in Eaton Bay Trust also ruled that the renewal was merely an extension agreement, not a novation. It went on further (despite the Carlyle case) to rule that the renewal did not amount to a material altera-

31. In Holland-Canada Mortgage Co. v. Hutchin, supra n. 29, see text at n. 61.

32. Burnesv. Trade Credits Ltd. [1981] 1 W.L.R. 805 (P.C.).

33. (1983) 30 R.P.R. 254.

34. (1984) 139 A.P.R. 199.

35. (1979) 28 O.R. (2d) 27 (Div. Ct.).

36. Supra n. 26. 
tion that could not be enforced against the original covenantor. In that regard, it is again noted that the renewal here reduced the interest rate, although that does not appear to be the basis of the decision.

In Bank of Montreal v. Miedema, ${ }^{37}$ again a mortgage was in place when the mortgaged property was sold. Thereafter, the purchasers renewed at a $71 / 4$ per cent rate increase. The lender sought personal judgment against both the original borrower and the purchasers. Although the purchasers had not signed any assumption agreement, by their transfer they (by law) indemnified the transferor and by the renewal agreement they covenanted with the lender to pay as per the renewal. The renewal went on to say that it was "entered into without novation". Subsequent to renewal, a modification agreement was entered into by the purchasers, reducing the principal by about 1,000 dollars and granting, bonus-free ten per cent prepayment rights. All other terms and conditions of the original mortgage were ratified and confirmed.

Van der Hoop L.J.S.C., simply applied the ruling in Eaton Bay Trust, although he stated that it seemed to him that the renewal and modification agreements should have released the original borrower. In that regard, since the purchasers here had covenanted directly with the mortgagee, the case was not really on all fours with Eaton Bay Trust.

An interesting case out of Nova Scotia is Central Trust v. Adshade. ${ }^{38}$ There the mortgagee lined up the various mortgagors past and present and Mr. Bartlett (one of the prior owners) defended on the basis that the renewal was done without his consent and without notice to him. Bartlett succeeded at trial, but lost in the Court of Appeal.

The trial judge, Richard $J$. founded his decision on basic principles of fairness: It would be patently unjust for the mortgagee to enter into the material alterations of the renewal and still be able to seek recourse against a prior owner (whom Richard J. labelled a "guarantor"), who had neither consented to nor been notified of the change. Richard J. indicated that he was tempted to find a novation qua "the guarantor", but founded himself instead on the "justness" base. Presumably in that regard, the basis of his decision is that the material alteration of the mortgage transaction operated as a release of the guarantor (the prior mortgagor).

The Court of Appeal ruled that there was no novation of the mortgage and that no principle of suretyship applied to the prior owner. However, enforcement against the prior owner was restricted to the interest rate applicable before renewal. In this case, the initial purchaser had signed an assumption agreement (which was contemplated in the "due-on-sale" clause in the mortgage). The same occurred on subsequent sales and each assumption expressly reserved the rights under the original mortgage and against the original mortgagor. It was in those special circumstances that the Court of Appeal was unable to find a novation.

On the suretyship issue, the Court founded itself on the Ontario Court of Appeal decision in Forster v. Ivey. ${ }^{39}$ However, for purposes of Alberta

37. (1983) 30 R.P.R. 264.

38. (1983) 57 N.S.R. (2d) 35, reversed sub. nom Central Trust v. Bartlett (1983) 30 R.P.R. 267.

39. (1901) 32 O.R. 175. 
law, one should be careful before applying this precedent: mortgages in Alberta are special creatures of statute (the Land Titles Act makes them mere changes), and the Alberta Court of Appeal viewed the prior mortgagor's position as one like suretyship: Devenish v. Connacher. ${ }^{40}$ This makes Forster v. Ivey inapplicable to Alberta, as under our Land Titles Act, there is a direct covenant relationship between a mortgagee and a transferee. This point of distinction for the Alberta position has also, as previously indicated, been made in one of the British Columbia cases, ${ }^{41}$ in a Prince Edward Island decision ${ }^{42}$ and in two Ontario decisions of recent date. ${ }^{43}$

An approach very similar to this Court of Appeal decision seems to have been taken in a recent judgment of Feehan J. in National Bank of Canada v. Rosario, ${ }^{44}$ although that case did not involve any change in ownership. The mortgage was a corporate mortgage guaranteed by several guarantors. Without the knowledge of any but one guarantor, the mortgagee and mortgagor amended the mortgage to provide for a higher interest rate. The guarantee expressly contemplated variance of the mortgage between the lender and the mortgagor not af fecting the guarantees. There was here no question of title transfer or alteration of the parties' legal characters.

Discussing extensively the cases dealing with release of guarantees and contracting out of such release (culminating in Bauer v. Bank of Montreal), ${ }^{45}$ Feehan J. concluded that the guarantee contract expressly excluded release of the guarantee by the alteration. However, his Lordship then went on to note that the guarantee undertook only to pay principle and interest as provided in the mortgage (not as later amended), and therefore the guarantee applied only to the original rate, not the increased rate. The one guarantor who was aware of the increase and signed the instrument of increase (one presumes he signed as borrower's of ficer, not as a guarantor) was, however, bound to the increased rate. ${ }^{46}$

Some further Alberta cases of interest on the subject of "novation" and release include the following:

40. Supra n. 28. See also Re Forster Estate (1941) 3 W.W.R. 449 (Alta. S.C.); Wald v. Pape, supra $\mathrm{n}$. 35. Note however the suggestion of Beck J., in Netherlands Investment Co. v. Des Brisay [1928] 1 W.W.R. 461 (Alta. C.A.) that the liabilities of successive mortgagors may be "several liabilities for the same debt" (p. 469). Master Funduk saw in the express language of Clarke J.A., in Devenish v. Connacher at least a triable issue as to whether a prior mortgagor is truly a "surety": Winterburn Inv. Ltd. v. Taj Investments Ltd. (unreported, 10 November 1983, J.D. of Edmonton, 8203-28477).

41. Eaton Bay Trust Co., supra n. 33.

42. Royal Trust Companyv. Reid, supra n. 34.

43. Waldv. Pape, supran. 35; and Malaviya v. Lankin, supra n. 26.

44. (1984) 35 Alta. L.R. (2d) 276; 60 A.R. 8 (Alta. Q.B.). This decision has been followed by Master Quinn in Bancorp Financial Limited v. Ranfurly Investments Ltd., unreported, 11 July 1985, J.D. of Edmonton, 8303-07449 (Alta. Q.B.) and Bank of Montrealv. Thomson, unreported, 22 July 1985, J.D. of Edmonton, 8503-05589 (Alta. Q.B.).

45. (1980) 110 D.L.R. (3d) 424 (S.C.C.).

46. A similar case and decision by Master Funduk preceding the Rosario judgment is Victoria and Grey Trust Co. v. Hagan, unreported, 6 December 1984, J.D. of Edmonton, 840323581. 


\section{Credit Foncier Franco Canadienne v. 253171 Alberta Ltd. 47}

In this appeal from Master Funduk's decision, Purvis J. held that the renewal in question was not a novation. The renewal was done by letter in a fairly coventional form which was accepted by the property owner. At the time that the renewal was completed, there was a second mortgage in place and it was the second mortgagee who was attacking the renewed mortgage. The second mortgagee claimed that on the renewal the mortgage had been novated" and as a result it stood behind the second mortgage in priority. That position failed because it was clear from the wording of the renewal itself that the parties intended that the original mortgage would still remain in place. On the other hand, the court did rule that the new rate of interest affected by the renewal did not operate as against the second mortgagee and the increase in interest rate accordingly took a second position to the second mortgage.

The decision of Master Funduk, ${ }^{48}$ was expressed somewhat differently. Its orientation was more to the question of whether the original mortgage covenants had been estinguished by the renewal. Master Funduk held that, while there was no liability on the personal covenant on the original mortgage because of s. 41(1) of the Law of Property Act, there was still a debt which remained when the mortgage was transferred and assumed by the corporate purchaser. The effect of the extension was to give the corporate purchaser more time to pay the debt. Even if it created a personal liability to pay on the part of the company purchaser, which did not exist previously because the original mortgagor was an individual, the debt was not extinguished but continued through the extension of the mortgage.

\section{I quote at length from Master Funduk's decision:49}

The emphasized parts of the agreement [the renewal] speak for themselves. The plaintiff was merely giving further time for the payment of the debt secured by the mortgage. There was a cost to the defendant for that further time, being (a) an increase of the interest from $111 / 2 \%$ to $191 / 2 \%$, and (b) the defendant's covenants to pay the debt, interest as agreed, and to observe all the other covenants in the mortgage.

Prior to the agreement there was no personal liability on the part of the defendant to the plaintiff. It is an essential foundation of the defendant's position that the agreement created a personal liability by the defendant to the plaintiff and that personal liability replaced the Jansen debt.

Assuming, without deciding, that the agreement created a personal liability by the defendant to the plaintiff, I do not agree that had the effect of extinguishing the Jansen debt.

The Jansen debt continued to exist after the agreement of June, 1982. The plaintiff now had as "collateral" (additional) security for the payment of the debt. The personal covenant of the defendant to pay the debt no more replaces the covenants by Jansen (albeit unenforceable) to pay the debt than do the covenants by a guarantor to pay the debt replace the covenants by the mortgagor to pay the debt. The fact the covenant by Jansen is not enforceable while the covenant by the defendant is (assuming it to be) does not mean the second covenant replaces the first. Both remain. By way of analogy it is like the situation in Edmonton Airport Hotel Co. Lid. v. Credit Foncier Franco-Canadien, [1965] S.C.R. 441.

47. (1984) 33 Alta. L.R. (2d) 276.

48. [1984] A.W.L.D. \#638, unreported, 16 May 1984, J.D. of Edmonton, 8203-28332 (Alta. Q.B.).

49. Id. at 8-10. 
What happened here is like a case of a person who buys goods from a merchant on credit. When the due date for payment arrives a friend of the buyer goes to the merchant and says - if you will extend the time for payment I promise to pay you and to pay you $X \%$ interest. The merchant agrees. The effect is that, in addition to whatever other remedies the merchant may have for collection of the debt, he now also has additional security in the sense that he has an additional pocket to look to for payment. The additional pocket does not extinguish the debt. It reinforces the merchant's ability to be able to successfully collect what is owed him.

Whether or not the additional interest would be effective against Laurentide if it wanted to redeem is academic. There is no issue between the plaintiff and Laurentide and Laurentide does not seek to redeem.

The defendant cannot use its covenants to pay the debt, or its covenant to pay the additional interest, to indirectly bootstrap itself and the guarantors ahead of the plaintiff by seeking to elevate Laurentides' charge above the plaintiff's charge.

1 find, on the interpretation of the June, 1982 agreement, that the Jansen debt continued to exist, that the Jansen mortgage continued to exist, and that the Jansen mortgage is prior to the Laurentide mortgage.

The following quote from Commercial Life Assurance Company, is appropriate:

"In the case at bar the situation is entirely different. The extension agreement does not purport to create a new indebtedness. It is not treated as such in the extension agreement, in the statement of claim or in the order nisi, as appears clearly from the references 1 have already made to them. In all of these the original debt is treated as existing but with a reduction from the amount of the interest accrued up to December 1 , 1938. ..." (p. 598)

That is also applicable to the agreement in question here.

\section{Bank of Montrealv. Michaud ${ }^{50}$}

This is a decision of the Court of appeal on an appeal (ultimately) from Master Quinn. The sole issue on the appeal was whether an assumption agreement worked a "novation" of the mortgage contract.

The Court of Appeal stated, as per Stevenson J.A.: ${ }^{51}$

I regret to say that it is not possible to find a novation. The requirements of a novation are referred to in Investors Mortgage Security Company, Ltd. v. McDonald and Henry [1927] 1 W.W.R., 671, where the following is said:

"In a case like the present where it is alleged that a new person - has become party to a new contract, it must appear not only that he has entered into an obligation with the creditor for a definite consideration to pay the old debt, but that there exists an understanding between the old debtor and the creditor whereby the creditor has agreed to accept the new debtor in substitution of the old one and has released the latter from further obligation."

Those elements are not present here. This appeal must be allowed.

I say that I regret this conclusion because under existing legislation the respondents would escape personal judgment. Unfortunately that legislation is not retroactive and the only source of assistance is not the courts but the legislature.

The limited statement of the case result leaves its precedent value uncertain.

\section{Credit Foncier Franco-Canadien v. Alico Development Corporation Ltd. 52}

In this case the mortgage was originally a corporate mortgage and the lender sued the original corporate borrower, personal guarantors of the mortgage, and a Mr. Wiebe who had purchased the property and assumed the mortgage.

50. Unreported, 22 May 1984, J.D. of Edmonton, 16920 (Alta. C.A.).

51. Id. at 1-2.

52. Unreported, 26 August 1983, J.D. of Edmonton, 8203-42416 (Alta. Q.B.), Master Quinn. 
Mr. Wiebe had assumed the mortgage by agreement to assume, dated the 28th day of February, 1979, which provided that he agreed to assume the mortgage "to the same extent as if the covenantors had been the original mortgagors and as such had executed the same". In addition, the mortgage had been renewed for a term of five years in February of 1982. On the renewal, the mortgage rate increased from $11^{1 / 4}$ per cent to $181 / 2$ per cent.

Mr. Wiebe's argument was that the wording of the assumption agreement itself prevented any recourse over on his personal covenant to pay by virtue of s. 41(1) of the Law of Property Act. Master Quinn rejected that argument by saying: ${ }^{53}$

\footnotetext{
In my opinion the mere fact that Alfred Wiebe had covenanted in the particular terms above quoted does not have the effect of making him an original mortgagor. He remains merely a person who has assumed the mortgage and cannot be viewed as a person who has originally given the mortgage. The assumption agreement does not purport to release the original mortgagor, Alico Development Corporation ("Alico") from any liability, and it cannot be said that the assumption agreement is a novation.
}

One might query whether the answer given by the learned Master addresses the substance of an issue that might have been raised (or that was perhaps the one intended to be raised) by Mr. Wiebe. Could the position taken by Mr. Wiebe be, simply, that all he agreed to do was to assume the obligation under the mortgage to the same extent as if he had been the original mortgagor? By that he would mean that he assumed it to an extent that is limited by the Law of Property Act (which would be the case if he had been the original mortgagor). That would not be the same as saying that the assumption agreement made him the original mortgagor; it would merely qualify the extent to which he assumed the mortgage.

$\mathrm{Mr}$. Wiebe also argued that the renewal agreement was a new mortgage agreement between himself and the lender and that s. 41(1) of the Law of Property Act accordingly applied. Master Quinn noted that the renewal agreement did not suggest that Alico had been released in any fashion and that the renewal agreement did not have the ef fect of releasing Alico from its obligation to pay the plaintiff. He quoted from a passage in Falconbridge on Mortgages (fourth edition, pages 299 and 300) to the effect that the relationship between mortgagee, the original mortgagor, and a person who assumes the mortgage is not that of creditor, surety and principal debtor. Unfortunately the statement from Falconbridge may be subject to some question in this province in the light of some longstanding Alberta decisions, particularly the Devenish v. Connacher case mentioned above. The position so expressed may be inconsistent with the special position for Alberta arising out of the direct implied covenant with the mortgagee under s. 62 of the Land Titles Act.

\section{Royal Bank of Canada v. Ulderink ${ }^{54}$}

In this decision Master Funduk followed the B.C. Supreme Court decision in Canada Permanent v. Carlyle discussed above.

The decision itself is very brief and one is constrained to presume some of the facts. It would appear that the mortgage would originally have

53. Id. at 2-3.

54. Unreported, 24 July 1984, J.D. of Edmonton, 8303-30388 (Alta. Q.B.) Master Funduk. 
been placed by the parent defendants and the property subsequently transferred into the name of both the parents and their two sons. There was then an extension agreement which appears (one presumes) to have been signed only by the parents (the mortgagee appears not to have known of the transfer).

The sons claimed that their position under the mortgage had been released by the extension agreement and that the mortgage did not apply to their half interest in the land. Master Funduk did not accede to that argument and in so doing relied on the Carlyle case. He indicated that even if the sons as co-owners did not sign the renewal agreement, they were, at best, not personally liable; but that did not mean that the mortgagee couldn't enforce its charge against the land.

\section{Killips v. Leroda Management Ltd. ${ }^{55}$}

In this case a mortgage was originally granted by Southridge Properties (1975) Ltd., and assumed on property transfer by Leroda Management Ltd. It provided for annual principal and interest payments and an interest rate of ten per cent. After taking title, Leroda entered into an agreement with the lender providing for deferral of certain sums with higher interest obligations on some portions deferred. When default subsequently occurred the lender sought judgment against Southridge on its covenant to pay as original mortgagor. Southridge argued first that it was, after transfer of the land, a mere surety and was released by the mortgage extension and secondly that the extension was a novation. Both arguments failed.

In regards to the "surety" argument, Master Breitkreuz (whose decision was affirmed on appeal by Agrios J.) held that the characterization of the prior mortgagor as a "surety" for some purposes did not make him a surety for all purposes. He relied on some old Ontario decisions, discussed further below, that may be superceded by the distinctions drawn by Devenish v. Connacher ${ }^{56}$ between Alberta and jurisdictions that do not create a direct contractual nexus between a mortgagee and a transferee.

On the question of novation the learned master ruled that because Southridge was not a party to the extension there could be no novation, saying:

In order for a novation to take place, the parties to the original contract must also be parties to the alleged novation.

Further, there was no agreement nor understanding by the mortgagee that the burden of the mortgage contract had shifted from the original mortgagor to the purchaser. In that regard he cited, in addition to Canada Trustco Mortgage Co. v. Stonewood ${ }^{57}$ and Bank of Montreal v. Michaud, ${ }^{58}$ the old Alberta decisions of Canada Life Assurance Co. v.

55. Unreported, 5 September 1984, J.D. of Edmonton, 8203-44673 (Alta. Q.B.), Master Breitkreuz; affirmed by Agrios J., on appeal 6 February 1985.

56. Supran. 28.

57. (1983) 28 Alta. L.R. (2d) 92 (M.C.).

58. Supran. 50. 
Young ${ }^{59}$ and Commercial Life Assurance Co. v. Debenham. ${ }^{60}$ The first three cases are summarized herein. The fourth case, Debenham, involved an extension arrangement, on an agreement for sale of land, made bettween the original parties to the agreement for sale; and thus has limited value in grappling with the issues applicable to a mortgage and its renewal with a subsequent mortgagor.

On the appeal before Agrios J., counsel argued the applicability of four New Zealand decisions ${ }^{61}$ that outlined a concept of novation applying to subsequent purchasers' renewals. The New Zealand equivalent to our $\mathrm{s} .62$ provided no direct covenant with the mortgagee. Novation was nonetheless found. The characterization of the prior mortgagor as a "surety" was rejected, however, because of the absence of a direct covenant on the part of the transferee. Agrios J., in any event, decided not to follow the New Zealand decisions.

\section{Canada Trustco Mortgage Co. v. Stonewood Developments Ltd.62}

This is a decision of Master Quinn addressing a situation in which renewals had been made with subsequent transferees. However, the liability claim against the original corporate mortgagor was not contested, and such mortgagor was noted in default. It was the current owner-defendants who sought to characterize their own renewals as some form of novation that, being a "new" contract with individuals, would be subject to s. 41 of the Law of Property Act. ${ }^{63}$

The Learned Master could find no basis for interpreting the relationships of the parties as involving any release of the original mortgagor from responsibility. Indeed, the renewals expressly stated that they were made "without novation." In those circumstances Master Quinn ruled there to have been no novation.

The Learned Master noted that the Holland-Canada Mortgage Co. v. Hutchings case, ${ }^{64}$ relied upon by the defendants (and which is further discussed below) dealt with release of sureties, and as such of fered no help to the defendant current owners.

\section{Holland - Canada Mortgage Co. v. Hutchings}

This decision of the Supreme Court of Canada on appeal from the Alberta Appellate Division was followed in the Carlyle case. ${ }^{65}$ It involved

59. [1921] I W.W.R. 915 (Alta. S.C.).

60. [1940] 3 W.W.R. 592 (Alta. C.A.).

61. Nelson Diocesan Trust Board v. Hamilton [1926] N.Z.L.R. 342; Paterson v. Irvine [1926] N.Z.L.R. 352; Public Trustee v. Mortleman [1928] N.Z.L.R. 337; and Grove v. Public Trustee [1931] N.Z.L.R. 1071.

62. Supra n. 57.

63. R.S.A. 1980, c. L-8. The argument may be less far-fetched than it might, at first blush, seem. If, as suggested in the Netherlands Investment case (supra n. 400, successive mortgagors are co-covenantors, do they then collectively make the mortgage one by a mortgagor group that includes individuals and thereby bring into play a restrictive interpretation of $s$. 43 of the Law of Property Act as applied in Chateau Developments Ltd.v. Steele (1983) 46 A.R. 188 (Alta. C.A.), leave subsequently refused by S.C.C. (31 Alta. L.R. xl)?

64. [1936] S.C.R. 165, [1936] 2 D.L.R. 481 (see supra n. 31).

65. Supra n. 30. 
the position of sureties under written guarantees, but the position was taken in Carlyle to be similar for a prior mortgagor.

The case is somewhat similar to the Burnes v. Trade Credits Ltd. case. ${ }^{66}$ General guarantees of a mortgage had been given. The terms of the mortgage were altered subsequently increasing the rate of interest. Particulars of the change were not disclosed fully to some guarantors who appeared to assent and particulars were withheld from other guarantors inducing them to refuse assent to the alterations. The surety contracts contained provisions to the effect that they would continue "no matter what dealings" occurred between the mortgagee and the mortgagor and that the surety obligations would continue as long as any money remained unpaid under the mortgage or "any renewal or extension thereof". The extension agreements expressly reserved rights of the creditor against sureties, but the sureties were not made parties to the extension agreements.

The Court held that the stipulations in the surety contracts did not entitle the creditor to make a new contract with the borrowers and still hold the sureties bound. A renewal or extension with an increased rate of interest was not merely something collateral but a definite alteration of a material part of the original contract. A surety is a "favoured creditor in the eyes of the law", and his obligations are "strictly examined and strictly enforced". Davis J., speaking for the whole court (which included Duff C.J. and Rinfret, Crocket and Kerwin JJ.) stated:68

"It must always be recollected," said Lord Westbury in Blest v. Brown, 4 De G. F. \& J. 367, at p. 376, 45 E.R. 1225, "in what manner a surety is bound. You bind him to the letter of his engagement. Beyond the proper interpretation of that engagement you have no hold upon him. He receives no benefit and no consideration. He is bound, therefore, merely according to the proper meaning and effect of the written engagement that he has entered into. If that written engagement be altered in a single line, no matter whether it be altered for his benefit, no matter whether the alteration be innocently made, he has a right to say. "The contract is no longer that for which I engaged to be surety; you have put an end to the contract that 1 guaranteed, and. my obligation, therefore, is at an end."

Apart from any express stipulation to the contrary, where the change is in respect of a matter that cannot "plainly be seen without inquiry to be unsubstantial or necessarily beneficial to the surety," to use the language of Rowlatt, The Law of Principal and Surety, 2nd ed., p. 102, the surety, if he has not consented to remain liable notwithstanding the alteration, will be discharged whether he is in fact prejudiced or not. Holme v. Brunskill(1877), 3 Q.B.D. 495.

Subsequently, when addressing the position of 2 guarantors who appeared subsequently to consent to the extensions (but who were not provided with all the material facts), the learned justice said: ${ }^{69}$

While I cannot accept the contention of counsel for the respondents that there was the creation of a new debt and the extinguishment of the old debt, there were such material changes in the original contract as to call for full disclosure to the sureties and assent to such changes if the sureties were to be rendered liable for the contract as varied.

Finally, disposing of the extension agreements' reservation of rights against sureties the Court said: ${ }^{70}$
66. Supran. 32.
67. Supran. 61 at 172; 486.
68. Id.
69. Id. at $174 ; 488$.
70. Id. at 176; 489 . 
But it is said that both the extension and renewal agreements reserved the rights of the sureties by express language in the instruments. It is quite a different matter, however, to reserve the rights against the surety in an agreement mercly extending the time for payment and to reserve the rights against the surety in an agreement materially altering the old contract. This was clearly pointed out by Street J., in Bristol \& West of England Land, Mtge \& Investment Co. v. Taylor (1893), 24 O.R. 286, where he said, at pp. 2967 , that "the words reserving the creditor's rights against the surety, however effectual they may be in so far as the extension of time is concerned, are mere 'idle words' in so far as any effect upon the stipulation for an increased rate of interest is concerned."

\section{Canada Life Assurance Co. v. Young 71}

This is an early (before Devenish v. Connacher) ${ }^{72}$ decision on the enforceability of the mortgage covenant against a prior mortgagor. The original mortgage provided that part of the security might be released without releasing the mortgage covenants. A subsequent owner of the mortgaged property entered into an extension agreement with the mortgagee increasing the interest rate. Part of the lands were released from the mortgage, although it appears from the decision that the original mortgagor consented to the land release. The mortgagee relinquished any claim to the increased interest rate. The extension was made expressly without prejudice to any rights against any surety or other person.

In the circumstances the court held the mere extension of time to pay did not release the original mortgagor, unless, he could show some impairment of his rights to proceed against the subsequent owner.

\section{Investors Mortgage Security Company, Limited v. McDonald ${ }^{73}$}

This old Saskatchewan case also warrants mention under this heading. While the case concerned itself firstly with limitation of actions questions, it also addressed the issues of novation and covenant release.

There had been several transfers of land followed by payment extensions, including an interest rate increase. The extension agreement negatived merger and expressed itself as not altering or prejudicing the rights of the lender as against any surety or other person. Mackenzie $J$. held that for there to be a novation it must appear not only that the new debtor had entered into an obligation to pay the debt, but that there existed an understanding between the old debtor and the creditor whereby the creditor had agreed to accept the new debtor in substitution for the old and has released the later from further obligation. He found the intent of the parties in this case to be quite the contrary, and "novation" did not therefore apply.

As to the alteration in interest rate releasing the original mortgagor the court said: 74

In view, however, of the fact that the defendants [the original mortgagors] are not parties to such agreement [the extension agreement], and that such changes were not made and did not take effect until after the maturity of the said mortgage, and especially because of the clause in the said agreement to which $I$ have already referred and which

71. Supran. 56.

72. Supra n. 28.

73. [1927] 1 W.W.R. 671 (Sask. K.B.).

74. Id. at 676. 
declares that it shall not only not prejudice the rights of the plaintiff but of any other person interested in the land, I have come to the conclusion that it does not constitute such a discharge: Trust \& Loan Company v. McKenzie 23 O.A.R. 167, at p. 170; Canada Life Assur. Co. v. Young [1921] 1 W.W.R. 915.

It should be noted that the plaintiff claimed interest only at the rate originally contracted, not the increased rate. In addition, the principles expressed in the McKenzie case relied upon were subsequently suggested by our Court of Appeal to be inapplicable to Alberta, whose Land Titles Act provisions (now s. 62) create a direct contractual nexus between the mortgagor and the mortgagee. ${ }^{75}$

It should be noted as well that the Manitoba Court of Appeal in Potash ${ }^{76}$ was firm on the thought that a renewal was not a new mortgage. Other cases are occurring on a monthly basis. ${ }^{77}$

By way of wrap-up of the discussion under this heading it might be noted that the idea of release could apply whether or not the prior mortgagor is a "surety" or a co-covenantor. If the alteration is material and not agreed to by the prior mortgagor, even if he is characterized as a direct contracting party or co-covenantor, should he not be discharged (as Carlyle suggests)? The one factor that "suretyship" of the original mortgagor would add is the rather more restrictive treatment of surety liability by the law. Save for that, should not the principles and their application be the same?

\section{PRIORITIES}

There should be no real question that the priority position of renewals should operate on normal Land Titles principles. Unless registered and given priority by postponements, renewals at increased rates simply will not be effective against registrations subsequent to the original mortgage and prior to the renewal. One exception made to that would be writs of execution filed after making of a renewal. Writs can only bind what the mortgagor has. Another might be mortgages that in their original form contemplate renewals and express them to be binding with the same priority and benefits of the original term (although one needs first to determine what is the legal nature of a renewal to be sure of this possibility).

Several cases have been reported on this issue:

\section{Canada Trust Co. v. Hart ${ }^{78}$}

In this case, the mortgage itself provided that the interest rate could be modified on the extension of a mortgage. In foreclosure proceedings an

75. Devenish v. Connacher, supra n. 40 at 259 . At the time of the decision in Trust \& Loan Companyv. McKenzie, 23 O.A.R. 167 and the subsequent Forsterv. Iveycase, supra n. 39, which followed McKenzie, the Ontario legislation did not create a direct contract nexus between a mortgagee and a transferee. That difference from Alberta's Land Titles Act s. 62 (as it was in 1930) formed the basis for distinction by Mr. Justice Clarke of the Forster case as inapplicable to the Alberta situation.

76. Supran. 12 at $224 ; 146$.

77. For example; Montreal Trust \& Co. v. Sinclair (1984) 32 R.P.R. 275 (B.C.S.C.); Montreal Trust v. Sharp (1984) 32 R.P.R. 261 (B.C.S.C.).

78. (1983) 27 R.P.R. 37 (B.C.S.C.). 
issue arose as to priority of the renewal arrangement over subsequent encumbrances. The extension raised the interest rate but fortunately for that mortgagee, the extension was made before the second mortgage was made. McDonald $\mathrm{J}$. held that in view of the provision in the mortgage itself, any modification made before a subsequent encumbrance was completed would take effect against that encumbrance, although he clearly stated that a modification made subsequent to a subsequent encumbrance being made would not.

\section{Canada Trust Co. v. Heyer 79}

Nemetz C.J. held in this case that, although a renewal agreement changing the mortgage rate by an eight per cent increase was not a new mortgage (or novation), it was not effective as against subsequent mortgagees whose mortgages were in place before the renewal. It should be noted that on the novation issue, the renewal here was made by the original mortgagor.

\section{Meincke v. Edmonton Savings \& Credit Union ${ }^{80}$}

McFadyen J. considered in this case an extension agreement on a chattel mortgage. Competing execution creditors claimed that a new chattel mortgage should have been registered. The Court held that the agreement did not create a new loan, that a new chattel mortgage was not required, and that the priority position was accordingly not affected.

\section{Sherwood Credit Union Limited v. Arthur Ward ${ }^{81}$}

In this case, the original loan was for 60,000 dollars with a three-year term at $101 / 4$ per cent, and the mortgage provided that any costs incurred by the lender in enforcing the provisions contained in the mortgage would be on a solicitor-client basis. The borrowers placed a second mortgage and then a third mortgage on the property subsequent to the 60,000 dollars mortgage in question. Subsequently, the borrowers executed a renewal agreement for the 60,000 dollars first mortgage at a rate of $171 / 2$ per cent. The first mortgage contained a paragraph that said that any agreement for renewal or extension of the term of payment of monies need not be registered but would be "effectual and binding on the mortgagor and on any subsequent owner of the mortgaged premises or any parts thereof, when deposited in or held at any of fice of the mortgagee".

MacLean J. relied on the above-cited provision in the first mortgage to give priority for the renewal interest rate. He said:

In my view there is no merit in the bank's [second mortgagee's] submission. At the risk of pointing out the obvious, it was clearly not the intention of the parties that the mortgage be paid in full by December 1, 1980. Unless the Wards [the borrowers] borrow sufficient funds elsewhere to retire the mortgage they will from time to time be required to execute renewals at various interest rates until the mortgage is fully paid.

When the bank took its second and third mortgage, it is presumed to have had knowledge of the terms of the plaintiff's mortgage.

79. (1983) 27 R.P.R. 213 (B.C.S.C.).

80. (1982) 44 A.R. 22 (Alta. Q.B.).

81. Unreported, 11 July 1983, J.D. of Regina, 2254 (Sask. Q.B.). 
Paragraph 14 [the one cited above] contemplates renewals of the mortgage with varying interest rates. In the absence of some scheme between the plaintiff [the first mortgagee] and the Wards to grossly inflate the interest rate to the prejudice of the bank, the plaintiff is entitled to the rate of interest as provided in the renewal agreement.

\section{Fraser Valley Credit Union v. Carlson ${ }^{82}$}

In this case the British Columbia Supreme Court held that mortgage amending agreements did take priority as against later judgments filed in the Land Titles system where the mortgage amendments were made prior to such filing.

\section{Caisse Populaire de Maillardville Credit Union v. Butt ${ }^{83}$}

The B.C. Supreme Court held in this case that the second mortgagee was not affected by the terms of the renewal of the first mortgage. As a result, the additional interest accruing on the renewal fell behind the second mortgage in priority.

\section{Vancouver City Savings Credit Union v. McKinnon ${ }^{84}$}

The British Columbia Supreme Court held in this case that amendments to a mortgage (which increased the interest rate) were not effective as against subsequent encumbrancers who had no notice of the amendments.

\section{Fraser Valley Credit Union v. Carlson ${ }^{85}$}

The British Columbia Supreme Court gave a mortgage extension or renewal agreement priority over registered judgments (writs of execution). The renewal was made prior to the entry of the judgments in the land titles records and the higher rate of interest included in the mortgage renewal agreement took priority over the writs accordingly.

\section{9. $\operatorname{Re} C I B C^{86}$}

The B.C. Court of Appeal held in this case that a second mortgagee, who redeemed a defaulted first mortgage, that had been amended (to increase the interest rate) after the second mortgage was placed, was obligated to pay only an amount based on the original first mortgage interest rate. Effectively, the mortgage amendment fell behind the second mortgage.

\section{MATERIAL ALTERATION}

A number of the cases already cited have likened the position of a prior mortgagor who has not been joined in a renewal to the position of a contracting party whose contract has been altered without his consent. As

82. (1984) 50 B.C.L.R. 39 (S.C.).

83. (1983) 50 B.C.L.R. 135 (S.C.).

84. (1983) 50 B.C.L.R. 35 (S.C.).

85. (1984) 31 R.P.R. 102 (B.C.S.C.). For a similar case from Ontario see Reynolds Extrusion Co. Ltd. v. Cooper (1978) 21 O.R. (2d) 416 (H. Ct.).

86. (1984) 14 D.L.R. (4th) 282 (B.C.C.A.). 
previously indicated, the scope for that principle applying in Alberta is considerably wider than it is in some other provinces. That seems due in part to the creation, by s. 62 of the Land Titles Act, of a direct covenant with the mortgagee by subsequent transferees and in part to the precedent of Devenish v. Connacher ${ }^{87}$ that treats the position of a prior mortgagor like that of a surety.

While the Killips case ${ }^{88}$ pursuasively suggests a relatively narrow operation of the "surety"' concept drawn from Devenish, it does so by drawing on old Ontario authorities. In particular, Master Breitkreuz cites at length from Trust \& Loan Companyv. McKenzie: ${ }^{89}$

There is no doubt that when a mortgaged land is sold by a mortgagor subject to a mortgage a sort of suretyship results, but it is altogether between the mortgagor and his vendee. The vendee is the person who as between them ought to pay, the debt is now his debt, and the mortgagor is his surety. But the mortgagee's position has not been changed. The mortgagor is the only debtor, and the land alone is still his only security. The expression "principal debtor" used in cases of suretyship imports that there is another debtor, namely, the surety.

The present case is therefore not a case of suretyship at all within the decisions as to discharge of surety by dealings without his consent between the creditor and principal debtor. It is really only a case of indemnity. [Emphasis added.]

However, at the time, the Ontario statute equivalent to s. 62 of Alberta's Land Title Act did not create a direct contractual nexus between mortgagee and transferee. That was a significant basis for Devenish v. Connacher's distinguishing away the Ontario decisions; ${ }^{90}$ and noting the tenor of the express language above cited, that distinction seems persuasive (if not plainly valid). The Ontario Supreme Court has now so held twice as well. 91

If, indeed, the prior mortgagor is on a wider basis truly a surety, then there should be every reason to be concerned about the application of cases regarding release of sureties, such as in Holland-Canada Mortgage Co. ${ }^{92}$ discussed above.

The position of a guarantor who is not joined in a renewal will depend very much on the express wording - particularly exculpatory provisions - of the instrument containing the covenant. Unlike guarantee forms, however, which nowadays typically bear exculpations that exclude virtually all manner of defences (as suggested by the Supreme Court of Canada in Bauer v. Bank of Montreal) ${ }^{93}$ it would be unusual indeed to find a mortgage document that contains those same exculpations. Or, indeed, a mortgage that goes even so far as to say that the mortgagor's covenant will apply notwithstanding sale and renewal at higher rates by a subsequent purchaser.

The legal effect of the release of a guarantor by material alteration may therefore apply a fortiori to the position of a mortgagor in the position of

87. Supran. 28.

88. Supran. 55.

89. 23 O.A.R. 167 at 170.

90. Specifically Forsterv. Ivey supran. 39, which followed McKenzie.

91. Wald v. Pape, supra n. 27 and Malaviya v. Lankin, supran. 26.

92. Supra n. 31. See also the Privy Council decision in Burnes, supra n. 32, and Veit J.'s decision in Alberta Financial Consultants Ltd. v. Cuthbert (1984) 55 A.R. 147.

93. (1980) 110 D.L.R. (3d) 424. 
a surety (after transfer), whose "surety" defences have not been exculpated. A couple of cases, drawn from a host of guarantee cases, may suffice to illustrate the problem, when added to the decisions already mentioned above on mortgage renewals. ${ }^{94}$

\section{Bank of Nova Scotia v. Bulych ${ }^{95}$}

In this decision of the Saskatchewan Court of Queen's Bench, a guarantee was held to be released by alteration of the financial arrangement with the debtor unilaterally by a bank. The bank had agreed to give the debtor company an operating line of credit of 100,000 dollars maximum, and to advance funds once all the security for the loan was in place. Part of the security was a 25,000 dollar personal guarantee given by an outside party which, contrary to the terms stipulated by the bank's regional office, was never supported with collateral. The defendants executed their guarantees believing that all security was in place and that the company's line of credit was fully approved. They were not told anything to the contrary and the bank began advancing funds. After 90,000 dollars was advanced to the borrower the bank limited the operating loan to 75,000 dollars pending receipt of the security for the 25,000 dollar guarantee, which the bank discovered later was in fact the guarantee of the debts of one of the defendants, and not of the company. As a result of the credit restrictions, the venture failed, the bank made demand on its loan and the company went into receivership. The bank's action on the personal guarantees was dismissed on the basis that what had in fact occurred was not the contract for which the defendants undertook to be surety.

\section{Alberta Financial Consultants Ltd. v. Cuthbert ${ }^{96}$}

This is a most unusual decision of the Alberta Court of Queen's Bench on a matter of landlord and tenant law that expresses principles that could be applied to mortgage sureties. A landlord had entered into a lease with the Cuthberts. Some eighteen months later, the Cuthberts assigned their leasehold interest to a third party. The landlord joined in the assignment by way of an undertaking in which the landlord accepted "the assignee as assignee of the assignor's interest in and under the said lease", and subject to the condition that the assignor was not released. ${ }^{97}$ Veit $\mathrm{J}$. held that by entering into the assignment agreement, the landlord had altered the role of the original tenant to that of a surety. The continued obligation of the original tenant she held to be a guarantee and since there was no notary certificate, the landlord was not entitled to enforce the original tenant's covenant. Veit J. also held that where the landlord joins in the assignment, he somehow gives up the right to sue the original tenant notwithstanding the express reservation of right.

94. Eg., Carlyle, supran. 30 and the trial decision in Central Trust v. Bartlett supra n. 38.

95. [1984] 3 W.W.R. 746. See also Toronto-Dominion Bank v. Rooke (1983) 3 D.L.R. (4th) 715; and Burnesv. Trade Credits Ltd., supra n. 32.

96. Supran. 92.

97. The position of the landlord so expressed is quite common for landlords who wish to consent to an assignment but retain prior covenants. 
The decision is surprising (and debatable) in at least two respects. First of all, the characterization of the original tenant as a guarantor is arguably wrong on any issue between the landlord and that tenant. Indeed, the very case Her Lordship cites in this regard ${ }^{98}$ makes it clear that the characterization of "suretyship" really is no more than saying that there is an indemnity right between the assignor and assignee and it doesn't suggest or alter the nature of any relationship with the landlord (that is, the "surety" concept is the limited kind described in the McKenzie case above cited). On the other hand, if an assignee of a lease becomes directly liable to the lessee, perhaps those restricted characterizations do not apply. Secondly, the cases cited by Her Lordship to support the statement: ${ }^{99}$

Where, instead of merely assigning his estate in demised premises under hand or by deed, a lessee arranged that the landlord should be a party to the contract of assign-

ment, the lessee can be relieved of the ongoing obligation to pay rent.

don't really address the situation Her Lordship had before her. ${ }^{100}$ Nonetheless, the case stands and is unlikely to be appealed. It remains therefore a precedent of some interest.

Applying the case to the mortgage context, it warrants support for the position of a prior mortgagor as being that of a surety. Especially in those cases where a lender requires a purchaser to be approved and enter into an assumption agreement (as with mortgages with "due on sale" clauses), if this case is right, then the original mortgagor or transferor becomes a guarantor. Then too, perhaps even a notary's certificate would be needed (although this part of the Cuthburt decision remains most debatable).

In any event, whether the original mortgagor becomes a true surety or merely a co-covenantor, the material alteration of the terms of liability clearly remains a route for his escape from liability after renewal by a subsequent owner.

\section{POINTS APPARENT FROM THE STATUTES AND CASES}

From these recent cases, some things become clear in the matter, or handling, of renewal transactions. First of all, it remains possible that a renewal could operate as some kind of novation (and/or as an accord and satisfaction as to the original mortgage), although not one of the Alberta cases has reached such a conclusion to date. On balance, it seems unlikely that novation will be found in most cases. Avoidance of the danger

98. Warnfordv. Duckworth (1979) Ch. 127.

99. Supran. 92 at 149.

100. The one case cited is an Ontario Court of Appeal decision, under the name of Montgomery v. Spence (1983) 23 U.C.Q.B. 39, dealing simply with pleadings in an action. A tenant had argued that the landlord had on the assignment released the original tenant. That plea did not succeed. The second case, Chancellor v. Poole (1871) 99 E.R. 488, rules almost opposite to the proposition for which it is cited. In that case, a tenant had further assigned a lease and relied on the law that says a mere assignee ceases to be liable on the covenant of a lease once he ceases to be the tenant/occupant. The landlord claimed that having joined in a deed with that assignee who took the lease from the original tenant, the assignee had become a direct lessee/covenantor with the landlord. The Court upheld the assignee's position, not the landlord's, indicating in so doing that for the landlord to be able to treat the assignee as if he were an original lessee, the document would have to make that clearly the arrangement. 
might, however, be achieved first of all by expressly negativing novation and accord and satisfaction; but, more importantly, by avoiding the substance of them. What becomes clear, then, is that the renewal form in all cases should both negative novation (and accord and satisfaction) and express itself as a modification (not a replacement) of the existing mortgage's terms that leaves the existing mortgage otherwise fully intact.

Secondly, if third party covenants (whether those of guarantors or prior mortgagors) are to be preserved with certainty they should be joined in the renewal instrument. And, for safety, anyone who bears the capacity of surety or guarantor, if not a company, should be the subject of a completed Guarantees Acknowledgement Act notarial certificate.

Needless to say, if the land and subsequent parties dealing with the land are to be bound by the change, something must be registered at Land Titles Office. The only mechanism for registration (unless the mortgage is simply replaced by a new mortgage) to this date is the caveat. ${ }^{101}$ In addition, encumbrances in place that are subsequent to the original mortgage will probably have priority over the renewal unless they are postponed. That is possible, notwithstanding s. 106.1 of the Land Titles Act, even if the mortgage expressly contemplates renewal (depending, on this point, on what is the ultimate treatment by the courts of the nature of the renewal transaction).

If the renewal or extension is not a novation and is made between a current owner and the mortgagee, and if prior owners are not joined in the instrument, then the instrument may not operate as an amendment of the mortgage. If not, then s. 62 covenants may not apply to subsequent purchasers. However, whether or not that is the case, it should be clear that, to ensure in rem attachment of any increase in rates or benefits available to the mortgagee on the renewal, they must be specifically charged by the renewal agreement and of course caveated on the title. (On the other hand, one might be concerned about the additional charging provision in the renewal agreement adding to its possible characterization as a "novation".)

If the original mortgage is a corporate mortgage and it is desired to retain the character of the ongoing extended loan transaction as a corporate mortgage, then at the very least that intent should be reflected expressly in the renewal agreement where the current owner is an individual. Such expression will not guarantee the operation of the renewal agreement as an extension of a corporate mortgage; but certainly may help. It would be even better if the corporate grantor of the mortgage could join in the change to reflect continuance of the mortgage's corporate character and to retain at least the corporate grantor's covenant enforceability.

It should go without saying that the lender should never expressly release the original covenant by his renewal. Indeed, the renewal should always expressly refer to the retention of all rights on prior and other covenants. Remembering that the primary and root part of any mortgage is the promise of the borrower to pay, releasing that covenant may well

101. Although the Land Titles Amendments set out in Bill 19 in the Spring 1985 sitting will, if proclaimed, allow direct registration of amending agreements. 
amount to a release of everything. ${ }^{102}$ Certainly if a release occurs in combination with a renewal or extension arrangement with a promise to pay by a subsequent owner, there is a serious risk of characterization of the arrangement as a "novation", in which event arguably the whole of the "novated" mortgage is to be found in the simple renewal form. 103

It is also important to keep an eye on the Interest Act and to avoid complications that might arise under that Act. There would be some danger in contemplating in the original mortgage itself the possibility of the mortgage bearing an altered unspecified interest rate at a future date or dates. Such concepts may amount to expressions in the mortgage of ideas that violate either or both of s. 6 and s. 8 of the Interest Act. While no harm should come from merely reflecting in the mortgage that there may at a future date be an agreement for altered terms of the mortgage, ${ }^{104}$ there should be no automatic arrangement built into the mortgage itself for future revision of the rates. Remember that while one (arguably) may solve the Land Titles Act priority problem by expressing such result in the mortgage itself, one may at the same time create either an Interest Act problem or confusion of the position of subsequent parties under s. 62 of the Land Titles Act.

102. On release of one of several co-covenantors operating to release all, see: Williams, Joint Obligations (1949), S. 50 and S. 63.

103. There are many potential complications that would arise out of the operation of the renewal as a new contract. Land Titles problems and prior covenant releases are not the only major concerns. If the contract is a new one, is it made within the limits of restrictive lending legislation (eg. if done by a trust company, does it comply with the $75 \%$ of value limit applicable under s. 122 of the Trust Companies Act, R.S.A. 1980, c. T-9? if done as an approved loan under the National Housing Act. R.S.C. 1970, c. N-10 is it still within the requirements for protection of that Act? etc.)? Any one of these points if successfully supported in the courts could do serious injury to the loan and in some cases (eg., ultra vires issues) be fatal.

104. Indeed, as the B.C.S.C. decisions in Montreal Trust v. Sinclair and Montreal Trust v. Sharp (supra n. 74) indicate, it may be determative. A precedent provision currently in use on some mortgage forms that hopefully avoids Interest Act complications is the following:

"In the event that the Mortgagee shall agree to renew or extend the term of this mortgage, such renewal or extension (and the rate of interest, term and instalment stipulations of such renewal or extension) shall be binding upon the Mortgagor, its successors in title and assigns, and all subsequent mortgages, encumbrances and other interests in the said lands (subsequent to this Mortgage and together hereinafter called "Subsequent Encumbrances") and shall take full priority over all Subsequent Encumbrances, whether or not the said renewal or extension is filed or recorded by caveat at the applicable Land Titles Office and whether or not the rate of interest payable or payment amortization period applicable during the renewal or extension term is greater than or less than (or the same as) the rate or amortization stipulated in this mortgage. The Mortgagor shall, forthwith on request therefor by the Mortgagee, provide to the Mortgagee, at the Mortgagor's expense, all such postponements and other assurances as the Mortgagee may require to ensure the foregoing binding effect and priority. All renewals (if any) shall be done at Mortgagor's expense (including without limitation payment of Mortgager's legal expenses on a solicitor-and-hisown-client basis). No such renewal, even if made by a successor in title to the Mortgagor named herein, shall in any way release or abrogate or render unenforceable the covenants or obligations of the Mortgagor named herein, which shall continue notwithstanding such renewal." 


\section{UNAVOIDABLE UNCERTAINTIES}

In the context of all the above, some areas of "incurable" problems (incurable short of legislative change) appear to be the following:

1. It may not be possible with certainty to avoid novation without losing some benefit of s. 62 on subsequent transfers and without triggering prepayment rights under the Interest Act. If the Land Titles Act contemplates only specificity in payment dates and amounts (see the express wording of s. 62 emphasised above) then perhaps the only sure renewal (in terms of direct enforcement of covenants on subsequent transferees) will be the entire replacement of a mortgage. While it seems doubtful that the mortgagee's in rem right will ever be lost as long as one registers the mortgage renewal, the in personum right to sue on covenants under s. 62 may not apply to the extension agreement if not joined in by all covenantors. Further, if renewal merely amends an existing mortgage, and does so by extending the term past five years, then s. 10 of the Interest Act may simply be unavoidable.

2. One can never guarantee to a lender that there will be no release of prior guarantors unless all such guarantors join in the mortgage renewal.

3. If the current owner who enters into the renewal agreement is an individual and the original mortgage is a corporate mortgage, one can not be certain of non-application of s. 41(1) to the renewal agreement. While the current expression of opinion (as per Master Quinn's views in the Alico case and the Stonewood case) would suggest that the character of the mortgage has not changed and that a renewal does not operate as a replacement of the original mortgage (but merely as an extension of it), it remains always possible that the matter could be viewed otherwise in the Court of Appeal if the right facts came before it.

4. Finally, there is no sure way of avoiding release of prior covenants short of requiring everyone in the covenant chain to join in the renewal. While it seems unlikely "novation" will be found in any reasonably drawn renewal agreement, the possibility of material alterations releasing prior covenantors is very real.

\section{CONCLUSION}

In short, renewal of mortgage is not the simple matter that its treatment a few years back suggested. Indeed, it may well behoove the lender who is looking at renewing a substantial mortgage to take no less interest in the process involved on renewal than he would take on the placement of the original mortgage itself. If critical covenants are released, or if a "novated" mortgage agreement is not properly recorded in a form that will secure its position on title, then the mortgagee may sadly learn too late how fatal careless documentation of a renewal can be. 